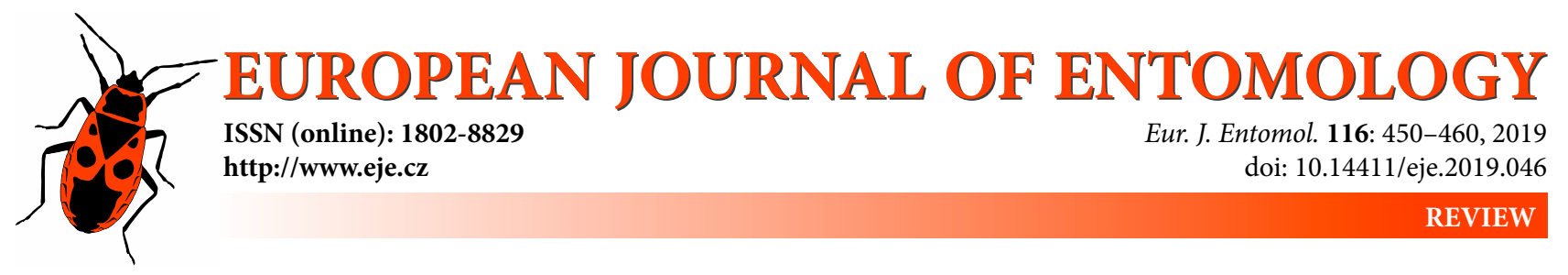

\title{
The entomofauna on Eucalyptus in Israel: A review
}

\section{Zvi MENDEL and ALEx PROTASOV}

Department of Entomology, Institute of Plant Protection, Agricultural Research Organization, The Volcani Center, Rishon LeTzion 7528809, Israel; e-mails: zmendel@volcani.agri.gov.il, protasov@volcani.agri.gov.il

Key words. Eucalyptus, Israel, invasive species, native species, insect pests, natural enemies

\begin{abstract}
The first successful Eucalyptus stands were planted in Israel in 1884. This tree genus, particularly E. camaldulensis, now covers approximately 11,000 ha and constitutes nearly $4 \%$ of all planted ornamental trees. Here we review and discuss the information available about indigenous and invasive species of insects that develop on Eucalyptus trees in Israel and the natural enemies of specific exotic insects of this tree. Sixty-two phytophagous species are recorded on this tree of which approximately $60 \%$ are indigenous. The largest group are the sap feeders, including both indigenous and invasive species, which are mostly found on irrigated trees, or in wetlands. The second largest group are wood feeders, polyphagous Coleoptera that form the dominant native group, developing in dying or dead wood. Most of the seventeen parasitoids associated with the ten invasive Eucalyptus-specific species were introduced as biocontrol agents in classical biological control projects. None of the polyphagous species recorded on Eucalyptus pose any threat to this tree. The most noxious invasive specific pests, the gall wasps (Eulophidae) and bronze bug (Thaumastocoris peregrinus), are well controlled by introduced parasitoids. Potential entomological hazards of Eucalyptus in Israel are most likely to originate from the Australian insect fauna.
\end{abstract}

\section{INTRODUCTION}

The first Eucalyptus plants were brought from Australia to the West in 1770 (Doughty, 2000). The earliest eucalypt seeds that reached Israel (Palestine at that time) were those of the Tasmanian blue gum, Eucalyptus globulus Labill. Apparently none of these trees survived for long (Karschon, 1963). The first successful Eucalyptus stands were planted in Israel in 1884 at the Mikveh Israel agricultural school (near Tel Aviv), probably consisting only of river red gum E. camaldulensis Dehnh. In the following years this species became the main Eucalyptus used in the first large-scale plantations in Israel (Karschon, 1963). In the first decades of Eucalyptus planting in Israel, its role in draining swamps proved important in the struggle against malaria (Rosen, 1991) which at that time posed a major challenge in southern Europe, particularly around the Mediterranean (Bruce-Chwatt \& Zulueta, 1980). In the last years of the $19^{\text {th }}$ century 200,000 E. camaldulensis seedlings were planted in the Northern Sharon area (known as Hedera forest) to drain the local wetlands and manage the mosquito populations (Liphschitz \& Biger, 2000). During those first 30 years, Eucalyptus comprised about a third of forest nursery production; its timber was harvested for agriculture and telephone poles and railway sleepers (El-Eini, 1999; Liphschitz \& Biger, 2000). Subsequently, Eucalyptus, mainly E. camaldulensis, was extensively planted in the Israeli low-altitude arid and semiarid lands. These stands form recreation areas, green belts surrounding neighbourhoods and agricultural areas, used for watershed management, sources of food for honeybees and a major source of timber and firewood. To date, Eucalyptus forests cover about 11,000 ha, half of which is planted with E. camaldulensis and much of the rest with E. gomphocephala DC (27\%) and E. occidentalis Endl. (12\%), the latter predominantly in desert or semi desert areas in the Negev (Fig. 1) (Anonymous, 2017). Some ninety-six species of Eucalyptus comprising between $2.5-5 \%$ of the total number of ornamental trees planted in public urban areas (about 25,000 ha) (Heller et al., 2017), 90\% of which consist of E. camaldulensis (Nazarian, 2016).

A number of species of insects from the native range of Eucalyptus in Australia have been unintentionally introduced into Eucalyptus-growing regions throughout the world. An increasing number of insects native to the territories where Eucalyptus trees were planted outside Australia, especially in the southern hemisphere, have shifted onto these trees and achieved pest status (Paine et al., 2011). By the late 19th century, Eucalyptus forests were being planted in most of the Mediterranean Basin. Currently, three species, E. camaldulensis, E. globulus and E. gomphocephala, dominate the areas planted in the Western Mediterranean (Algeria, Italy, Morocco, Portugal, Spain 


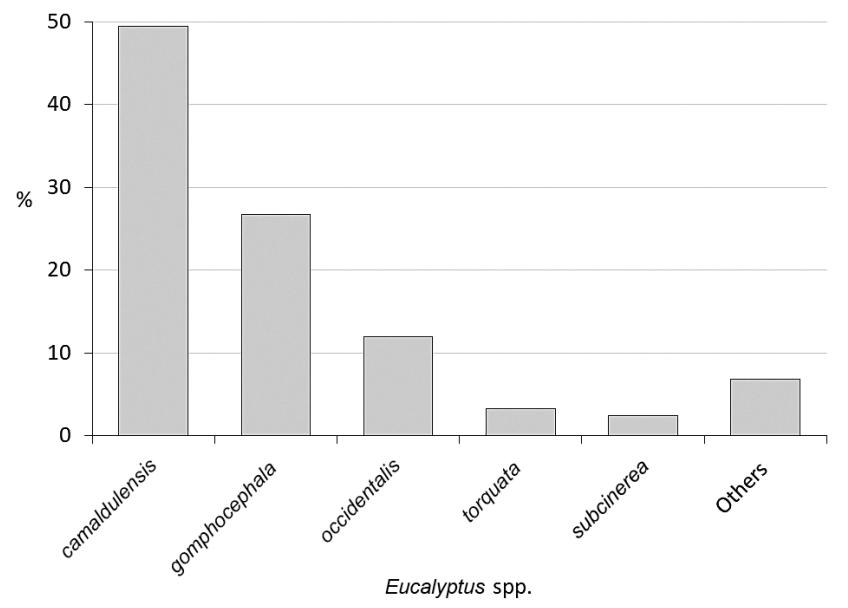

Fig. 1. Percentages of the different species of Eucalyptus planted in forests in Israel, which cover about 11,000 ha.

and Tunisia) which covers about 2.5 million ha. There is a lot of information about specific Australian invasive insects of Eucalyptus in the Mediterranean area (Kenis \& Branco, 2010; Maatouf \& Lumaret, 2012; Suma et al., 2018), but the presence of indigenous insects on Eucalyptus trees in these areas are rarely researched or reported.

Major threats to Eucalyptus plantations in Israel are posed by drought related to global warming, arson and invasive insect pests. By contrast, the overall damage to Eucalyptus in Israel caused by pathogens is limited and considered commercially insignificant. The present study reviews the information on the indigenous and alien invasive insects developing on Eucalyptus and their natural enemies in Israel.

\section{SOURCES OF DATA}

In this study, we processed and analysed both previous published records and the authors' observations over the last thirty years.

\section{RESULTS}

Sixty-two phytophagous species of insects have been found on Eucalyptus in Israel, about $60 \%$ of which are indigenous; the remaining originate from different areas and of which 16\% are Australian species (Fig. 2). Table 1 summarizes the information about fifty-two non-Eucalyptusspecific phytophagous insects occurring on Eucalyptus in Israel. None of these species are considered to be a major pest of this tree.

As expected, the insects living on Eucalyptus belong to different insect orders, with Hemiptera the major group and Coleoptera the second biggest group. Most of the Hemiptera are exotic, unlike the Coleoptera (Fig. 3).

Among feeding guilds, sap feeders constitute the largest group, followed by wood feeders (Fig. 4). Most of the insects were recorded from E. camaldulensis and it is very possible that those with no host record were also collected from this species of Eucalyptus. Few species were collected from several species of Eucalyptus and even fewer from species other than E. camaldulensis (Fig. 5).

Table 2 summarizes the specific invasive insects recorded on Eucalyptus. All ten species originated from Australia and seven of them were established in Israel in 2000. Among the eight phytophagous insect orders colonizing Eucalyptus there were no exotic species of Lepidoptera, Orthoptera or Isoptera (Fig. 3). Table 3 lists seventeen parasitoid species associated with the invasive Eucalyptus-specific species. Two species, Rhoptrocentrus piceus (Braconidae) (Halperin, 1976) and Megastigmus leptocybus (Torymidae) (Doganlar, 2015) are indigenous to Israel. Seven of the ten specific Eucalyptus insect species recorded in Israel are attacked here by one or more of their specific parasitoids (Table 3 ).

\section{DISCUSSION}

In Israel, as in many other countries, Eucalyptus trees are valued for their rapid growth and capacity for adapting

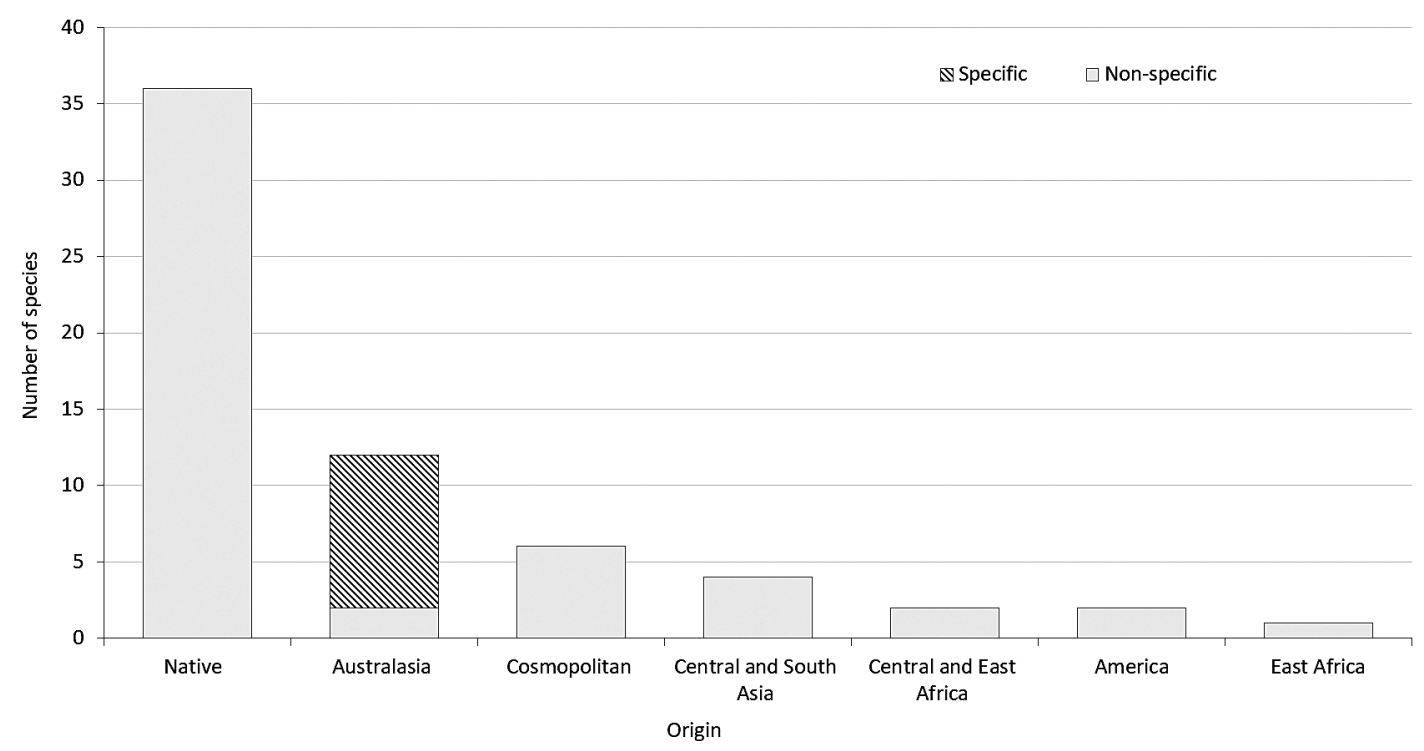

Fig. 2. Numbers of specific and non-specific species of the 62 phytophagous insects that occur on Eucalyptus in Israel according to their native area of origin. 
Table 1. Native and invasive nonspecific phytophagous insects on Eucalyptus spp. in Israel.

\begin{tabular}{|c|c|c|c|c|c|c|}
\hline Order & Family & Species & Origin & Feeding habit & $\begin{array}{l}\text { Eucalyptus and } \\
\text { Corimbia sp. }\end{array}$ & References \\
\hline \multirow{14}{*}{ Coleoptera (15) } & \multirow{2}{*}{ Curculionidae } & Achradidius milleri (Tournier) & Native & Defoliator & $\begin{array}{l}\text { camaldulensis }+ \\
\text { gomphocephala }\end{array}$ & Halperin, 1961a \\
\hline & & Hypothenemus eruditus Westwood & $\begin{array}{c}\text { Cosmopolitan, } \\
\text { invader }\end{array}$ & Wood feeder & camaldulensis & Authors' observ. \\
\hline & \multirow{3}{*}{ Cerambycidae } & Prinobius myardi (Mulsant) & Native & Wood feeder & spp. & $\begin{array}{l}\text { Halperin \& Holzschuh, 1993; } \\
\text { Sama et al., } 2010\end{array}$ \\
\hline & & Stromatium fulvum Villers & Native & Wood feeder & sp. $^{*}$ & Halperin \& Holzschuh, 1993 \\
\hline & & Penichroa fasciata Stephens & Native & Wood feeder & camaldulensis & Sama et al., 2010 \\
\hline & \multirow{6}{*}{ Bostrichidae } & Apate monachus Fabricius & $\begin{array}{l}\text { Central and } \\
\text { East Africa }\end{array}$ & Wood feeder & spp. & Peretz \& Cohen, 1961 \\
\hline & & Scobicia chevrieri (Villa \& Villa) & Native & Wood feeder & camaldulensis & Halperin \& Damoiseau, 1980 \\
\hline & & Trogoxylon impressum (Comolli) & Native & Wood feeder & sp. & $\begin{array}{l}\text { Halperin \& Geis, 1999; A.-L. } \\
\text { Fridman, pers. commun. }\end{array}$ \\
\hline & & Lyctus africanus Lesne & East Africa & Wood feeder & gomphocephala & Halperin \& Geis, 1999 \\
\hline & & Lyctus parallelocollis Blackburn & & Wood feeder & maculata & Halperin \& Geis, 1999 \\
\hline & & Xyloperthella picea Olivier & Native & Wood feeder & sp. & Halperin \& Damoiseau, 1980 \\
\hline & \multirow{2}{*}{ Buprestidae } & Acmaeodera pilosellae (Bonelli) & Native & Wood feeder & occidentalis & Halperin \& Argaman, 2000 \\
\hline & & Anthaxia diadema (Fischer) & Native & Wood feeder & occidentalis & Halperin \& Argaman, 2000 \\
\hline & Tenebrionidae & Opatroides punctulatus Brullé & Native & Wood feeder** & spp. & $\begin{array}{l}\text { Halperin, 1961b; } \\
\text { authors' observ. }\end{array}$ \\
\hline \multirow{16}{*}{ Hemiptera (16) } & Aleyrodidae & Aleurolobus marlatti (Quaintance) & Native & Sucker & camaldulensis & $\begin{array}{l}\text { Guershon \& Seplyarsky, } \\
2011\end{array}$ \\
\hline & \multirow{4}{*}{ Aphididae } & Aphis fabae Scopoli & Native & Sucker & camaldulensis & Swirski \& Amitai, 1999 \\
\hline & & Aphis gossypii Glover & Native & Sucker & $\begin{array}{c}\text { camaldulensis + } \\
\text { melliodora }\end{array}$ & Swirski \& Amitai, 1999 \\
\hline & & Myzus persicae Sulzer & Native & Sucker & camaldulensis & Swirski \& Amitai, 1999 \\
\hline & & Toxoptera aurantii Boyer de Fonscolombe & $\begin{array}{c}\text { Cosmopolitan, } \\
\text { invader }\end{array}$ & Sucker & $\begin{array}{l}\text { camaldulensis + } \\
\text { gomphocephala }\end{array}$ & Swirski \& Amitai, 1999 \\
\hline & \multirow{3}{*}{ Coccidae } & Ceroplastes floridensis Comstock & North America & Sucker & $\begin{array}{l}\text { camaldulensis } \\
\text { (greenhouse) }\end{array}$ & Authors' observ. \\
\hline & & Parasaissetia nigra (Nietner) & Africa & Sucker & $\begin{array}{l}\text { camaldulensis } \\
\text { (greenhouse) }\end{array}$ & Authors' observ. \\
\hline & & Protopulvinaria pyriformis (Cockerell) & $\begin{array}{l}\text { Cosmopolitan, } \\
\text { invader }\end{array}$ & Sucker & $\begin{array}{l}\text { camaldulensis } \\
\text { (greenhouse) }\end{array}$ & Authors' observ. \\
\hline & \multirow{3}{*}{ Diaspididae } & Aonidiella aurantii (Maskell) & Central Asia & Sucker & camaldulensis & Avidov \& Harpaz, 1969 \\
\hline & & Chrysomphalus aonidum (Linnaeus) & South Asia & Sucker & sp. & Ben-Dov, 2012 \\
\hline & & Hemiberlesia lataniae (Signoret) & $\begin{array}{l}\text { Cosmopolitan, } \\
\text { invader }\end{array}$ & Sucker & sp. & Ben-Dov, 2012 \\
\hline & Issidae & Agalmatium grylloides (Fabricius) & Native & Sucker & sp. & Avidov \& Harpaz, 1969 \\
\hline & \multirow{2}{*}{ Monophlebidae } & Icerya purchasi Maskell, & Australia & Sucker & camaldulensis & Authors' observ. \\
\hline & & Icerya aegyptiaca (Douglas) & South Asia & Sucker & camaldulensis & Authors' observ. \\
\hline & \multirow{2}{*}{ Pseudococcidae } & Planococcus citri Risso & Southeast Asia & Sucker & camaldulensis & Authors' observ. \\
\hline & & Pseudococcus viburni (Maskell) & Australasia & Sucker & camaldulensis & Authors' observ. \\
\hline Heteroptera (1) & Pentatomidae & Stenozygum coloratum Klug & Native & Sucker & camaldulensis & Authors' observ. \\
\hline \multirow{2}{*}{ Hymenoptera (2) } & Megachilidae & Megachile sp. & Native & Defoliator & spp. & Halperin, 1961b \\
\hline & Colletidae & Hylaeus sp. & Native & Pollen feeder & ficifolia & A. Dorchin, pers. commun. \\
\hline \multirow{2}{*}{ Isoptera (2) } & Rhinotermitidae & Reticulitermes clypeatus Lash & Native & Wood feeder & sp. & Halperin, 1973 \\
\hline & Termitidae & Microcerotermes palestinensis Spaeth & Native & Wood feeder & sp. & Halperin, 1973 \\
\hline \multirow{8}{*}{ Lepidoptera (8) } & Erebidae & Lymantria dispar (Linnaeus) & Native & Defoliator & camaldulensis & Authors' observ. \\
\hline & Geometridae & Ascotis selenaria (Denis \& Schiffermüller) & Native & Defoliator & camaldulensis & Halperin \& Sauter, 1991 \\
\hline & Lasiocampidae & Pachypasa otus (Drury) & Native & Defoliator & $\begin{array}{c}\text { camaldulensis+ } \\
\text { occidentalis }\end{array}$ & Halperin \& Sauter, 1991 \\
\hline & \multirow{5}{*}{ Noctuidae } & Agrotis segetum (Denis \& Schiffermüller) & Native & Defoliator & sp. & Halperin, 1961b \\
\hline & & Helicoverpa armigera (Hübner) & Native & Defoliator & camaldulensis & Halperin et al., 1989 \\
\hline & & Heliothis peltigera (Denis \& Schiffermüller) & Native & Defoliator & camaldulensis & $\begin{array}{c}\text { Halperin, 1961b (as } \\
\text { Chloridea); Halperin \& } \\
\text { Sauter, } 1991\end{array}$ \\
\hline & & Spodoptera exigua (Hübner) & Native & Defoliator & camaldulensis & Halperin \& Sauter, 1991 \\
\hline & & Spodoptera littoralis (Boisduval) & Native & Defoliator & camaldulensis & Halperin \& Sauter, 1991 \\
\hline \multirow{3}{*}{ Orthoptera (3) } & \multirow{3}{*}{ Acrididae } & Anacridium aegyptium (Linnaeus) & Native & Defoliator & camaldulensis & Halperin, 1961 \\
\hline & & Calliptamus barbarus palaestinensis Ramme & Native & Defoliator & camaldulensis & Halperin, 1961 \\
\hline & & Dociostaurus maroccanus (Thunberg) & Native & Defoliator & camaldulensis & Avidov \& Harpaz, 1969 \\
\hline \multirow{5}{*}{ Thysanoptera (5) } & \multirow{4}{*}{ Thripidae } & Florithrips traegardhi (Trybom) & Native & Sucker & camaldulensis & $\begin{array}{c}\text { Strassen \& Kuslitzky, } \\
2011-2012\end{array}$ \\
\hline & & Heliothrips haemorrhoidalis (Bouché) & Tropic America & Sucker & camaldulensis & Halperin et al., 1989 \\
\hline & & Mycterothrips acaciae Priesner & Native & Sucker & camaldulensis & Strassen \& Kuslitzky, 2012 \\
\hline & & Retithrips syriacus Mayet & Native & Sucker & spp. & $\begin{array}{c}\text { Strassen \& Kuslitzky, } 2012 \\
\text { and authors' observ. }\end{array}$ \\
\hline & Phlaeothripidae & Haplothrips gowdeyi (Franklin) & $\begin{array}{c}\text { Cosmopolitan, } \\
\text { probably } \\
\text { invader } \\
\end{array}$ & Sucker & camaldulensis & Strassen \& Kuslitzky, 2012 \\
\hline
\end{tabular}

* sp - single record, species of Eucalyptus was not indicated; ${ }^{* *}$ feeds on rotten Eucalyptus wood. 


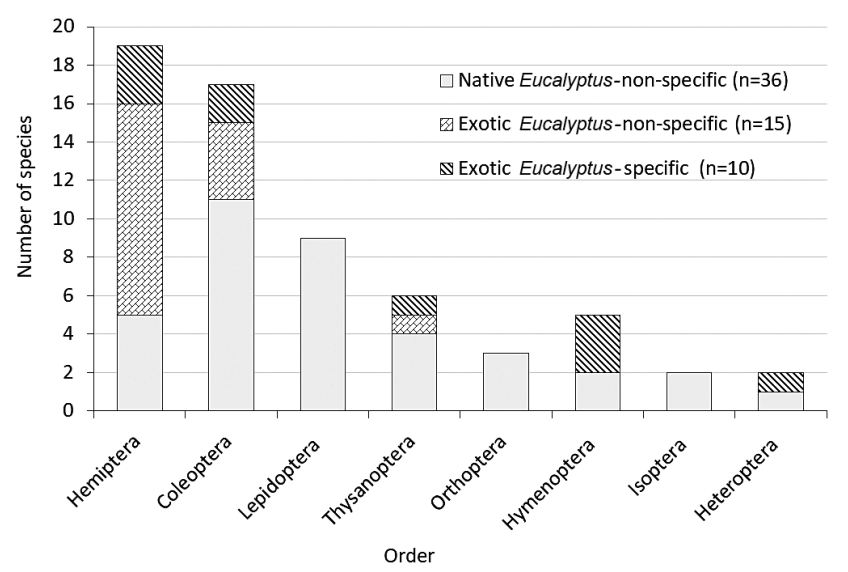

Fig. 3. Numbers of insects belonging to different orders of insects of the 62 phytophagous species of insects that occur on Eucalyptus in Israel according to their origin (indigenous vs exotic) and specificity to Eucalyptus.

quickly to different climates. Generally, insect pests are not a major threat to Eucalyptus plantations in Israel. However, both invasive and indigenous species may become a problem in the future. Among the sixty-three phytophagous species of insects recorded so far on Eucalyptus in Israel, thirty-seven are native, twenty-six are invasive and ten of the latter are specific to Eucalyptus.

\section{Sapsuckers}

Indigenous and invasive species of sapsuckers form the dominant group of insects on Eucalyptus in Israel. They are mostly found on Eucalyptus growing as ornamental trees in irrigated gardens, wetlands and along streams, which continue to grow during the long warm dry season. There are only slight changes in the cambial activity of $E$. camaldulensis, even under different climatic conditions or during different seasons of the year (Waisel et al., 1966). Water availability and an appropriate temperature regime are the main factors inducing seasonal changes in cambial activity (Kozlowski et al., 1991; Whitehead \& Beadle, 2004). This may well account for the long growth period of Eucalyptus trees growing where the supply of water is adequate during the dry season and their suitability for sap-

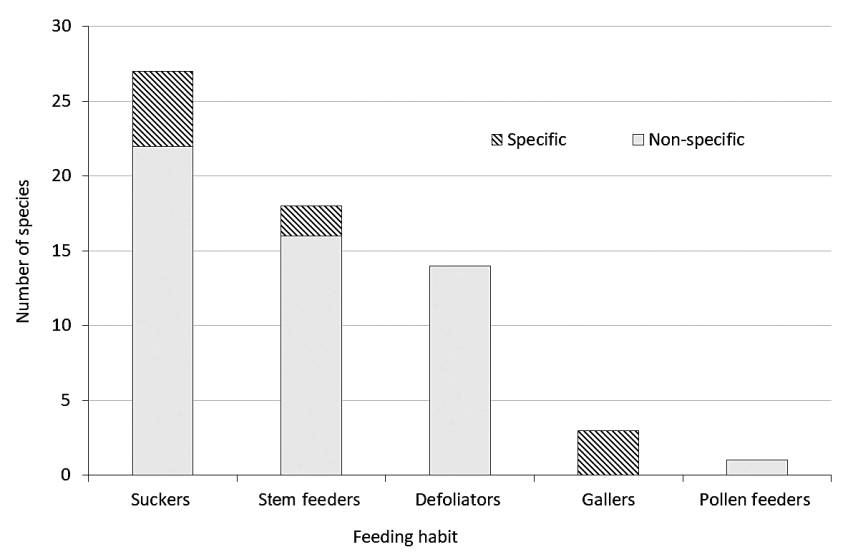

Fig. 4. Numbers of the 62 phytophagous insect species that occur on Eucalyptus in Israel according to their feeding habit and specificity to Eucalyptus.

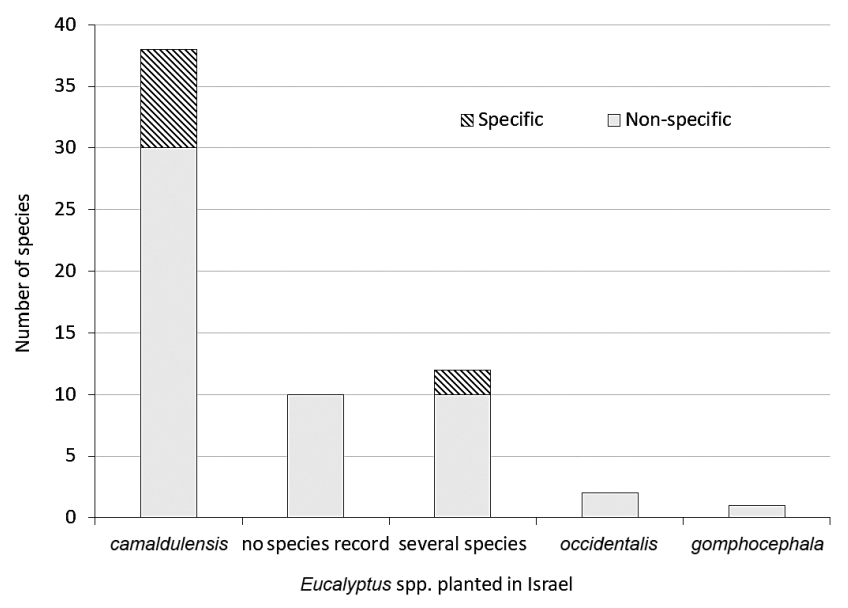

Fig. 5. Numbers of species of the 62 phytophagous insects that occur on Eucalyptus in Israel in terms of their recorded Eucalyptus host species in Israel and specificity to Eucalyptus.

suckers. In Israel, most of the sapsuckers are practically absent in planted forests where the trees only experience a short rainy season and consequently can only grow for a short period of time. Two of the Eucalyptus-specific sapsuckers, Glycaspis brimblecombei Moore and to a lesser extent Thaumastocoris peregrinus Carpintero and Dellapé are nevertheless still frequently recorded in forest plantations in the Northern and central areas in Israel (but see below for more about their biological control and pest status). The sapsuckers include six species of thrips, none of which are considered to be significant pests of Eucalyptus. Three are native; the invasive Thrips australis Bagnall (see below) is specific to Eucalyptus; Heliothrips haemorrhoidalis (Bouché) and Retithrips syriacus Mayet are minor pests of fruit trees.

The scale insects ( 10 species), thrips ( 5 species), aphids (4 species) and planthoppers (1 species) not specific to Eucalyptus (Table 1) are pests of many agricultural crops. However, their low frequency of occurrence on Eucalyptus indicate that these trees are not an important refuge for them or a significant source of these pests for agriculture. While the Hemiptera on Eucalyptus might constitute a refuge for their natural enemies, this possibility has yet to be studied.

\section{Stem borers}

Coleoptera form the second largest group of Eucalyptus insects in Israel and includes the highest number of indigenous species. Most of the species are woodborers, which are polyphagous and develop in the dying or dead wood of Eucalyptus trees. Together with two termite species (Table 1), these wood feeders are common in Eucalyptus plantations, where they exploit an abundance of dying and dead wood. The invasive borers Phoracantha semipunctata (Fabricius) and P. recurva Newman occur in many other countries (Paine et al., 2010). Both borers are very common in Israel (Golan, 2011) and other Mediterranean countries (Rassati et al., 2016). The frequent occurrence of these borers is due to the abundance of reproductive substrate in the form of trees dying due to drought or forest 
Table 2. Invasive Eucalyptus-specific phytophagous insects on E. camaldulensis in Israel.

\begin{tabular}{|c|c|c|c|c|c|}
\hline Order & Family & Species & Feeding habit & Year of discovery & References \\
\hline \multirow{2}{*}{ Coleoptera } & \multirow{2}{*}{ Cerambycidae } & Phoracantha recurva Newman* & Wood feeder & 2001 & Friedman et al., 2008 \\
\hline & & Phoracantha semipunctata (Fabricius) ${ }^{\star}$ & Wood feeder & 1945 & Bytinski-Salz \& Neumark, 1952 \\
\hline \multirow{3}{*}{ Hemiptera } & \multirow{3}{*}{ Aphalaridae } & Blastopsylla occidentalis Taylor & Sucker & 2008 & Spodek et al., 2015 \\
\hline & & Glycaspis brimblecombei Moore & Sucker & 2014 & Spodek et al., 2015 \\
\hline & & Platyobria biemani Burckhardt et al. & Sucker & 2015 & Burckhardt \& Spodek, 2015 \\
\hline \multirow[t]{2}{*}{ Heteroptera } & Thaumastocoridae & Thaumastocoris peregrinus Carpintero \& Dellapé & Sucker & 2014 & $\begin{array}{c}\text { Mendel \& Protasov, 2016; } \\
\text { Novoselsky \& Freidberg, } 2016\end{array}$ \\
\hline & & Leptocybe invasa Fisher \& La Salle & Gall maker & 2000 & Mendel et al., 2004 \\
\hline \multirow[t]{2}{*}{ Hymenoptera } & Eulophidae & Ophelimus maskelli Ashmead & Gall maker & 2003 & Protasov et al., $2007 a$ \\
\hline & & Quadrastichodella nova Girault & Seed gall maker & Before 1968 & Boucek, 1977 \\
\hline Thysanoptera & Thripidae & Thrips (Isoneurothrips) australis Bagnall ${ }^{* *}$ & Sucker & 1938 & Strassen \& Kuslitzky, 2012 \\
\hline
\end{tabular}

* Both Phoracantha spp. were also frequently collected from other species of Eucalyptus in Israel. ** In Australia, females feed primarily on the white flowers of various Eucalyptus species, and less commonly on those of other white-flowered Myrtaceae; adults may feed on plants of other families (Mound \& Masumoto, 2005); first record in Israel was on flowers of Prunus amygdali (Halperin \& Strassen, 1981).

fires, or fallen branches, the latter are frequently found beneath large Eucalyptus trees growing on wet sites. Neither these borers are primary pests of Eucalyptus in Israel and thus may serve as indicators of the physiological condition of the trees. There are many field studies on the resistance of Eucalyptus to Phoracantha (mainly P. semipunctata) (Chararas, 1969; Hanks et al., 1995), which indicate that the trees become susceptible to attack by these borers when they fail to cope with harsh environmental conditions, mainly as a result of drought. Dying Eucalyptus trees and dead wood are a refuge for polyphagous borers, e.g. the bostrichid Apate monachus Fabricius, which may switch to attack live trees of other genera, or the powder posts beetles Lyctus spp. and Stromatium fulvum Villers that damage timber and wood products. Generally, native Australian coleopteran borers have not become significant pests of Eucalyptus trees. However, a rather rich fauna of bark and ambrosia beetles have adapted to develop in $\mathrm{Eu}$ calyptus plantations in Brazil (Flechtmann et al., 2001), where many of these beetles are polyphagous and generalists, which is typical of many tropical species of scolytids. Lombardero and Fernández De Ana Magán (1997) report the presence of three native ambrosia beetles on Eucalyptus in Galicia (Spain), Xyleborinus saxeseni (Ratzeburg) and Xyleborus dispar (Fabricius) (Coleoptera: Scolytidae) and Platypus cylindrus (Fabricius) (Coleoptera: Platypodidae). Therefore, the rare occurrence of Hypothenemus eruditus Westwood on E. camaldulensis in Israel is not surprising (Table 1). Several species of cossid moths attack and breed on Eucalyptus in different areas outside Australia. Polyphagozeira coffeae Nietner and Neurozerra conferta Walker are recorded on Eucalyptus in south-eastern Asia (Yakovlev, 2011) and Chilecomadia valdiviana Philippi in Chile (Lanfranco \& Dungey, 2001) and Coryphodema tristis (Drury) in South Africa (Gebeyehu et al., 2005) are serious pests of Eucalyptus in those areas. Eucalyptus trees are also frequently planted in deserts in the Northern Hemisphere (Teketay, 2000; Jeddi et al., 2009). Despite the fact that the Mediterranean is rich in species of cossids (Yakovlev \& Dubatolov, 2013), there are no records of carpenter worms from Eucalyptus in this area. This is probably due to the absence of species of Myrtaceae that could serve as a source of species of cossids that could then develop on
Eucalyptus. The occurrence of Myrtaceae in the Southern Hemisphere probably facilitated the colonization of Eucalyptus there by cossids (Paine et al., 2010).

\section{Defoliators and Scarabaeidae}

The defoliators form the third largest group with thirteen species, all of which are native. The eight species of Lepidoptera form the second largest taxonomic group of native species. None of the defoliators are serious pests of Eucalyptus in Israel and few are considered important pests of other crops. Minor damage caused by the weevil Achradidius milleri (Boheman) and a leaf cutting bee Megachile sp. to recently planted Eucalyptus in the Coastal Plain soon after planting in the Western Negev is reported by Halperin (1961a, 1973). Megachile spp. observed in late spring, during the nesting period of the bees, may also have caused some damage to young trees soon after planting (Halperin, 1961b). Two other native defoliators, the Moroccan locust Dociostaurus maroccanus (Thunberg) and the cypress false silk moth, Pachypasa otus (Drury), are considered minor pests in Eucalyptus stands in dry areas in Israel. Rarely, local small outbreaks of the Moroccan locust may affect pockets of Eucalyptus trees planted in the Jordan Valley. The locusts are attracted to these trees, which are planted in earthen constructions that collect floodwater by damming a gully or streambed along the roads. In this area, these trees are the sole green vegetation remaining during the summer months. The native area of the cypress false silk moth $P$. otus is between Italy, Armenia and Iran, with different tree hosts in the different environments (Battisti et al., 2016). In Israel, although Cupressus sempervirens L. is the main host it develops on Eucalyptus in semi-desert areas. The defoliation due $P$. otus often remains unnoticed. However, when the mature larvae descend in great numbers prior to pupation, they may cause public concern due to the sensitivity of some people to the urticating hairs that are on the first abdominal segment of the last instar (Battisti et al., 2016). Mansfield (2016) indicates that among the native colonizers, leaf chewers in particular, quickly colonize Eucalyptus trees. In Israel, aside from D. maroccanus and P. otus, other local defoliators are rarely found on Eucalyptus. There is only a single record of Lymantria dispar (L.) on E. camaldulensis in Hadera (central Coastal Plain of Israel). Rare outbreaks of this gypsy moth are reported here 
on Quercus calliprinos Webb (Z. Mendel, unpubl. observ.). There are several reports of Lymantria dispar attacking E. camaldulensis in Italy (Roversi, 1995). Matsuki et al. (2001) also reports Lymantria dispar asiatica Vnukovskij feeding on a few species of Eucalyptus.

Although Scarabaeidae (Coleoptera) were not included in our survey, Ferreira et al. (1994) mention three species on E. globulus in Portugal; Anoxia australis (Gyllenhal), Anoxia villosa (Fabricius) and Melolontha papposa Illiger.

\section{Australian insects specific to Eucalyptus}

Ten species of Australian insects specific to Eucalyptus are presently established in Israel. Most if not all occur in other Mediterranean countries and in other Eucalyptusgrowing countries in the Americas and south Asia. Thrips australis was probably the first of this group to become established in this area. It is found both in Israel and elsewhere on many different plants and its females oviposit primarily on the white flowers of various Eucalyptus species (Mound \& Masumoto, 2005). Until 2000 P. semipunctata was the best known Eucalyptus insect in Israel; it was unintentionally introduced from South Africa on shipments of Eucalyptus wood used for fortifications during the early 1940s (Bytinski-Salz, 1966). During the last two decades, eight other species became established in this country. Phoracantha recurva, three psyllid species and the bronze bug $T$. peregrinus arrived in Israel from the central area of the Mediterranean, but the route taken by two of the gall wasps and T. australis is not clear. Leptocybe invasa Fisher and La Salle was discovered here in 2000 (Mendel et al., 2004) and Ophelimus maskelli Ashmead in 2003 (Protasov et al., 2007b). The third gall wasp, Quadrastichodella nova Girault was collected in Israel before 1968 (Boucek 1977); Zdenek Boucek wrote: “In 1968, when visiting Dr Erdos in Hungary, I saw specimens which he collected in Israel."; therefore, $Q$. nova could have been established here much earlier. Nine species develop on wide range of Eucalyptus species: $P$. semipunctata and $P$. recurva (Hanks et al., 1993), G. brimblecombei, Blastopsylla occidentalis Taylor (Luiz-Queiroz et al., 2012), Platyobria biemani Burckhardt et al. (Burckhardt et al., 2012), T. peregrinus (Wilcken et al., 2012), L. invasa (Mendel et al., 2004), O. maskelli (Protasov et al., 2007a) and T. australis (Mound \& Masumoto, 2005). Similarly, while it is possible that $Q$. nova might develop on other genetically closely related congeners of E. camaldulensis, in reality, only P. semipunctata and $P$. recurva thrive on various Eucalyptus species growing in Israel. All other species mentioned above have been observed only on E. camaldulensis, including L. invasa and $O$. maskelli after the establishment of their natural enemies (Mendel et al., 2017).

\section{Management and natural enemies}

In Israel, the management practices adopted, including chemical control and biological control, were directed against several species of the Eucalyptus-specific insects. The first management action was undertaken in the first half of the $20^{\text {th }}$ century and aimed at preventing the damage caused by $P$. semipunctata to telephone poles, which were then made of Eucalyptus trunks. To prevent damage by boring and powder post beetles (Lyctinae) the poles were impregnated with zinc chloride (Neumark, 1953). Later, a technique to protect fresh support poles made of Eucalyptus from damage by $P$. semipunctata was developed and extensively applied during the 1960s in fruit plantations in Israel. It consisted of spraying a $0.5 \%$ solution of lindane in a gasoil, which proved highly effective in eliminating or minimizing damage by borers (Chudnoff \& Spetter, 1962). Phoracantha semipunctata was the first of the Eucalyptus pests for which classical biological control was used. Of the several species of parasitoids that were sent from Australia to Israel in 1982, three braconids, Syngaster lepidus Brullé, Jarra phoracantha Marsh \& Austin and Liodoryctes sp., were released (Mendel et al., 1984b). For decades, there were no records of any of these parasitoids. In 2009 Liodoryctes sp. was recovered from a section of stem of $E$. camaldulensis colonized by both species of Phoracantha (Golan, 2011). Closterocerus chamaeleon (Girault), Stethynium breviovipositor Huber and Stethynium ophelimi Huber were collected in New South Wales, Australia for the control of Ophelimus maskelli; whereas Quadrastichus mendeli Kim \& La Salle, Selitrichodes kryceri Kim \& La Salle, Megastigmus lawsoni Doğanlar \& Hassan and M. zvimendeli Doğanlar \& Hassan were collected in Queensland, Australia, for use against Leptocybe invasa. Of these parasitoids six became established and successfully controlled the two gall wasps (Mendel et al., 2017). The establishment of $S$. breviovipositor is not yet confirmed. Cleruchoides noackae Lin \& Huber, an egg parasitoid of the bronze bug, was sent to Israel from South Africa in 2017. It was released and subsequently high levels of parasitism of colonies of the bug were reported at several locations and very few bugs were observed in the summer of 2019 (Mendel \& Protasov, in prep.).

Some of the most efficient Australian natural enemies fortuitously arrived and became established in Israel. Phoracantha recurva spread in the Mediterranean with its egg parasitoid Avetianella longoi Siscaro which was first reported in the central Mediterranean parasitizing P. semipunctata (Ben Jamaa \& Dhahri, 2009; Longo et al., 1993). This wasp attacks the eggs of $P$. semipunctata (Luhring et al., 2004) more effectively than those of $P$. recurva. In Israel, it is frequently recovered from eggs of both Phoracantha species, with no apparent effect on their population density (Golan, 2011). Similarly, to what happened in other countries in the Mediterranean area, Psyllaephagus bliteus Riek establishment followed the arrival of Glycaspis brimblecombei Moore (Laudonia \& Garonna, 2010; Boavia et al., 2016; Mendel et al., 2017). Megastigmus zebrinus Grissell was recorded recently together with its gall wasp host $Q$. nova (Mendel \& Protasov, in prep.) but the time of their establishment is unknown. The list of parasitoids and the year of their initial discovery, or recovery in Israel, is detailed in Table 3. In general, native insect enemies have switched to attacking the Australian insects that develop on Eucalyptus in Israel, but usually their role in regulating their numbers is insignificant. Generalist predators that 
Table 3. Parasitoids (Hymenoptera) of invasive specific phytophagous insects on Eucalyptus camaldulensis* that were established in Israel by classical or fortuitous biological control ("a" indicates the year of discovery of both native and non-native species, "n" refers to native species, "b" indicates the year of recovery of the introduced species).

\begin{tabular}{|c|c|c|c|c|}
\hline Family & Parasitoid & Host species* & $\begin{array}{l}\text { Year of first discoverya } \\
\text { or recovery in Israel }\end{array}$ & References \\
\hline \multirow[t]{3}{*}{ Braconidae } & Liodoryctes sp. & P. recurva, $P$. semipunctata & $2010^{b}$ & Golan, 2011 \\
\hline & Rhoptrocentrus piceus Marshall** & P. semipuctata & $1983^{\mathrm{a}, \mathrm{n}}$ & Halperin, 1986 \\
\hline & Syngaster lepidus Brullé & P. semipunctata & $1985^{\mathrm{b}}$ & Mendel, 1987 \\
\hline \multirow[t]{2}{*}{ Encyrtidae } & Avetianella longoi Siscaro & P. recurva, $P$. semipunctata & $2009^{a}$ & Golan, 2011 \\
\hline & Psyllaephagus bliteus Riek & G. brimblecombei & $2018^{a}$ & Protasov et al., in prep. \\
\hline \multirow[t]{3}{*}{ Eulophidae } & Closterocerus chamaeleon (Girault) & O. maskelli & $2005^{b}$ & Protasov et al., 2007a \\
\hline & Selitrichodes kryceri Kim \& La Salle & L. invasa & $2006^{b}$ & Mendel et al., 2017 \\
\hline & Quadrastichus mendeli Kim \& La Salle & L. invasa & $2006^{b}$ & Mendel et al., 2017 \\
\hline \multirow[t]{3}{*}{ Mymaridae } & Stethynium breviovipositor Huber ${ }^{* \star *}$ & O. maskelli & $2006^{b}$ & Mendel et al., 2017 \\
\hline & Stethynium ophelimi Huber & O. maskelli & $2006^{b}$ & Mendel et al., 2017 \\
\hline & Cleruchoides noackae Lin and Huber & T. peregrinus & $2018^{b}$ & Protasov et al., in prep. \\
\hline \multirow[t]{4}{*}{ Torymidae } & Megastigmus lawsoni Doğanlar \& Hassan & L. invasa & $2006^{b}$ & Mendel et al., 2017 \\
\hline & Megastigmus zvimendeli Doğanlar \& Hassan & L. invasa & $2006^{b}$ & Mendel et al., 2017 \\
\hline & Megastigmus leptocybus Doğanlar & L. invasa $a^{\star \star * \star}$ & $2001^{a, n}$ & Mendel et al., 2017 \\
\hline & Megastigmus zebrinus Grissell & Q. nova & $2019^{a}$ & Mendel et al., 2017 \\
\hline
\end{tabular}

${ }^{*}$ For more details see Table $2 .{ }^{* *}$ Develops in various cerambycids. ${ }^{* * *}$ Recovery was recorded once, establishment was not confirmed. ${ }^{* * * *}$ Not the original host.

typically prey on aphids and scale insects are frequently found in colonies of G. brimblecombei in Israel (Protasov et al., in prep.) and other areas (Erbilgin et al., 2004; Laudonia \& Garonna, 2010). Megastigmus leptocybus, a local parasitoid has become fortuitously associated with $L$. invasa galls, but its rate of occurrence is low and it occurs in only one area in Israel (Protasov et al., 2008). Native Megastigmus spp. are frequently recovered from galls of L. invasa in almost every country where this insect has become established (Doganlar, 2015). Mendel et al. (1984a) report that the Syrian woodpecker is an important predator of larvae of $P$. semipunctata and $P$. recurva. Golan (2011) reports high levels of predation of adults of the latter borer by bats and aggregation of the adult borers on Eucalyptus trap trees.

To date, nine of the ten Eucalyptus-specific phytophagous insects are not considered significant pests of live trees. Both Phoracantha spp. are reported as secondary pests developing on dying trees, or cut timber. The psyllids, B. occidentalis and P. biemani, the thrips T. australis and the gall wasp $O$. nova, occur at very low densities and are usually undetectable. The two gall wasps $O$. maskelli and $L$. invasa, and the bronze bug $T$. peregrinus are controlled by introduced parasitoids. The red gum psyllid $G$. brimblecombei is still a nuisance on ornamental E. camaldulensis trees, as the level of parasitism is less than $5 \%$, probably due to unfavourable climatic conditions during the main period of activity of the psyllid (Protasov et al., in prep.). Psyllaephagus bliteus was introduced into California in 2000 for the control of G. brimblecombei (Daane et al., 2005) and became established in Europe as a fortuitous biological control agent (Caleca et al., 2011; Perez et al., 2011). While in some tropical areas parasitism may be $>90 \%$ (Filho et al., 2015), in the Mediterranean area $P$. bliteus has a minor role in regulating psyllid populations. Therefore, the biological control provided by P. bliteus is not sufficient to prevent outbreaks of $G$. brimblecombei (Daane et al., 2012; Boavia et al., 2016; Margiotta et al., 2017).

\section{Other Eucalyptus-specific species in the Mediterranean}

Six other insects specific to Eucalyptus occur in the Mediterranean, but not in Israel. The potential hazard associated with these species is limited as they do not, or rarely attack the species planted here. Ctenarytaina eucalypti (Maskell) (Hemiptera: Aphalaridae) is narrowly hostspecific, feeding only on a limited range of Eucalyptus spp. that originate from temperate Australia and Tasmania, and is unsuited to a warm Mediterranean climate. However, in Italy it was recorded in 1982 and was for almost 20 years the only psyllid species known to develop on Eucalyptus spp. (Suma et al., 2018). The parasitoid Psyllaephagus pilosus Noyes appears specific to $C$. eucalypti and was successfully introduced into California and Europe (Hodkinson, 1999). Ctenarytaina spatulata has been present in Europe since 2003 (Valente et al., 2004). Its favoured host trees are not common in Israel and its performance on $E$. camaldulensis is poor (Queiroz et al., 2010). Two species of Eucalyptus snout beetles occur in Europe. One of them, Gonipterus platensis Marelli is present on the Iberian Peninsula, where it mainly attacks E. globulus (Gonçalves et al., 2019) (an uncommon tree in Israel) and is well controlled by the egg parasitoid Anaphes nitens (Girault) in a warm Mediterranean climate (Valente et al., 2018). The second species is an undescribed Gonipterus sp. (scutellatus complex) (Mapondera et al., 2012), established in Sicily, recorded on E. globulus but not on E. camaldulensis trees growing nearby (Mazza et al., 2015). Three species of Australian gall wasps (Hymenoptera: Eulophidae) occur in the west Mediterranean. Ophelimus mediterraneus is exclusively associated with Eucalyptus species from the Maidenaria section and mainly found on E. globulus in Italy, France and Portugal (Borowiec et al., 2019). Another eulophid, Epichrysocharis burwelli Schauff was detected for the first time in 2015 in Almada, Portugal, causing leaf galls on Corymbia (formerly Eucalyptus) citriodora (Hook.) (Franco et al., 2016); C. citriodora is a common 
ornamental tree in Israel. The third eulophid is Leprosa milga Kim \& La Salle, a seed gall inducer found in 2006 in Apulia, Italy (De Marzo, 2008).

\section{Shift of local insects to Eucalyptus and Eucalyptus-specific species to local vegetation}

Morphological classifications and molecular phylogenies suggest that the Myrtaceae family originated in Gondwana and most of its members naturally occur in the Southern Hemisphere and India (Thornhill et al., 2015). Native insects that have become pests on Eucalyptus outside Australia are generally either highly polyphagous, or have native Myrtaceae as their natural hosts. Insects in the latter group may be preadapted to shift to eucalypts as hosts (Paine et al., 2011). Brandle et al. (2008) suggest that after introduction the number of native species colonizing exotic plant species increases with time. However, as in California (Paine et al., 2011), the switch of a native herbivorous insect to becoming a serious pest of Eucalyptus in Israel is unlikely. Branco et al. (2015) examined 590 colonizations by native insects of exotic trees in Europe. These authors suggest that cases of major damage were positively correlated with the geographical extent of the exotic trees and the presence of congeneric native trees. The only Myrtaceae occurring in the Mediterranean basin are three Myrtus spp. that occur in the Mediterranean region of southern Europe, the Saharan mountains and Iran (Johnson \& Briggs, 1981), none of which naturally occur in Israel. There is no information on the insect fauna of Myrtus communis, the most common native member of Myrtaceae in the Mediterranean area. About 12 insect species are listed on M. communis in Israel, including scale insects ( 7 species), thrips, aphids and whiteflies (Avidov \& Harpaz, 1969; Y. Gottlieb, pers. commun.), all of which are polyphagous and most of them were also recorded on E. camaldulensis in our survey. None of the ten invasive species of insects specific to $E u$ calyptus (Table 2) are recorded occurring on M. communis in Israel. Furthermore, to the best of our knowledge, none of the specific phytophagous insects on Eucalyptus occur on members of tree genera other than Eucalyptus sensu lato in other areas. None of the Eucalyptus-specific species pose a threat to these trees in Israel, while the most noxious invasive species are well controlled by introduced parasitoids. Although the indigenous Australian insect fauna may constitute a potential threat to Eucalyptus in Israel, our experience suggests that their abundance can be controlled by the introduction of their specific natural enemies.

ACKNOWLEDGEMENTS. We gratefully acknowledge the assistance and support of foresters and gardeners in Israel in finding hot spots of insect infestations on Eucalyptus. We greatly appreciate the continuous collaboration of members of the forest health unit of the Forests Department KKL. We also thank M.R. Paiva (NOVA University of Lisbon, Portugal) and M. Branco (ISA, University of Lisbon, Portugal) for their suggestions on an early draft. We thank two anonymous reviewers for their valuable suggestions. This study was partly funded by KKL-JNF Project No. $131-1870$ of the ARO and 10-03-002-15 of the KKL.

\section{REFERENCES}

Anonymous 2017: Forest Management, Monitoring \& GIS. JNF Forest Department, Land Development Authority, Kiryat Haim, 27 pp.

Avidov Z. \& Harpaz I. 1969: Plant Pests of Israel. Israel Universities Press, Jerusalem, 549 pp.

Battisti A., Branco M. \& Mendel Z. 2016: Defoliators in native insect systems of the Mediterranean Basin. In Aine T. \& Lieutier F. (eds): Insects and Diseases of Mediterranean Forest Systems. Springer, Berlin, Heidelberg, pp. 29-46.

Ben-Dov Y. 2012: The scale insects (Hemiptera: Coccoidea) of Israel - checklist, host plants, zoogeographical considerations and annotations on species. - Isr. J. Entomol. 41-42 [20112012]: 21-48.

Ben JamaA M. \& Dhahri S. 2009: First record of Avetianella longoi, an egg parasitoid of Phoracantha semipunctata in Tunisia. - Tunis. J. Plant Prot. 4: 229-234.

Boavida C., Garcia A. \& Branco M. 2016: How effective is Psyllaephagus bliteus (Hymenoptera: Encyrtidae) in controlling Glycaspis brimblecombei (Hemiptera: Psylloidea)? Biol. Contr. 99: 1-7.

Borowiec N., La Salle J., Brancaccio L., Thaon M., Warot S., Branco M. \& Burks R. 2019: Ophelimus mediterraneus sp. n. (Hymenoptera: Eulophidae): A new Eucalyptus gall wasp in the Mediterranean region. - Bull. Entomol. Res. 109: 1-17.

BouceK Z. 1977: Descriptions of Tachinobia gen. n. and three new species of Tetrastichinae (Hymenoptera: Eulophidae), with a tentative key to genera. - Bull. Entomol. Res. 67: 1-25.

Branco M., Brockerhoff E.G., Castagneyrol B., Orazio C. \& JACTEL H. 2015: Host range expansion of native insects to exotic trees increases with area of introduction and the presence of congeneric native trees. - J. Appl. Ecol. 52: 69-77.

Brandle M., Kuhn I., Klotz S., Belle C. \& Brandl R. 2008: Species richness of herbivores on exotic host plants increases with time since introduction of the host. - Divers. Distrib. 14: 905-912.

Bruce-Chwatt L. \& Zulueta J. 1980: The Rise and Fall of Malaria in Europe. A Historico-Epidemiological Study. Oxford University Press, New York, 288 pp.

Burckhardt D. \& SPODEK M. 2015: Platyobria biemani (Hemiptera: Psylloidea: Aphalaridae), a new introduction into Israel and a potential pest of eucalypts. - Isr. J. Entomol. 44-45: 99-100.

Burckhardt D., Queiroz D. \& Malenovsky I. 2012: First record of the Australian genus Platyobria Taylor, 1987 from Europe and P. biemani sp. nov. as a potential pest of Eucalyptus (Myrtaceae) (Hemiptera: Psylloidea). - Dt. Entomol. Z. 124: 109-112.

BytinsKi-SAlz H. 1966: An annotated list of insects and mites introduced into Israel. - Isr. J. Entomol. 1: 15-48.

Bytinski-Salz H. \& Neumark S. 1952: The Eucalyptus borer (Phoracantha semipunctata F.) in Israel. In De Wilde J. (ed.): Transactions of the IXth International Congress of Entomology, Amsterdam, August 17-24, 1951. Amsterdam, pp. 696-699.

Caleca V., Verde G. \& Maltese M. 2011: First record in Italy of Psyllaephagus bliteus Riek (Hymenoptera: Encyrtidae) parasitoid of Glycaspis brimblecombei Moore (Hemiptera: Psyllidae). - Nat. Sicil. 3-4: 435-444.

Chararas C. 1969: Etude biologique de Phoracantha semipunctata F. (Coléoptère, Cerambycidae, xylophage) spécifique des Eucalyptus en Tunisie et recherches sur la vitalité et l'adaptation de ces essences. - C. R. Acad. Agric. Fr. 55: 45-57.

Chudnoff M. \& Spetter E. 1962: Control of Phoracantha semipunctata Fabr. by chemical spray. — La-Yaaran 12: 152-156 [in Hebrew]. 
DaAne K., Sime K., Dahlsten D., Andrews J. \& Zuparko R. 2005: The biology of Psyllaephagus bliteus Riek (Hymenoptera: Encyrtidae), a parasitoid of the red gum lerp psyllid (Hemiptera: Psylloidea). - Biol. Contr. 32: 228-235.

DaAne K., Sime K. \& Paine T. 2012: Climate and the effectiveness of Psyllaephagus bliteus as a parasitoid of the red gum lerp psyllid. - Biocontr. Sci. Technol. 22: 1305-1320.

De Marzo L. 2008: Ulteriori dati sulla presenza di Leprosa milga Kim \& La Salle su eucalipto in Sud Italia (Hymenoptera: Eulophidae). - Boll. Zool. Agrar. Bachic. 40: 227-232.

Doganlar M. 2015: Diagnosis of Megastigmus spp. (Hymenoptera: Torymidae) reared from galls of Leptocybe invasa on Eucalyptus spp. (Myrtaceae), with description of a new species from South Africa. - Entomofauna 43: 561-580.

Doughty R. 2000: The Eucalyptus: A Natural and Commercial History of the Gum Tree. Johns Hopkins University Press, Baltimore, MD, $237 \mathrm{pp}$.

EL-EINI R. 1999: British forestry policy in Mandate Palestine, 1929-48: Aims and realities. - Middle East Stud. 35: 72-155.

Erbilgin N., Dahlsten D. \& Chen P. 2004: Intraguild interactions between generalist predators and an introduced parasitoid of Glycaspis brimblecombei (Homoptera: Psylloidea). - Biol. Contr. 31: 329-337.

Ferreira M.C., Ferreira G.W.S. \& Fonseca N. 1994: Manual de Sanidade dos Viveiros Florestais. Instituto de Estruturas Agrárias e Desenvolvimento Rural, Lisboa, 493 pp.

Filho P., Wilcken C., Lima A., Nogueira L., Carmo J., Guerreiro J. \& ZANUNCIO J. 2015: Biological control of Glycaspis brimblecombei (Hemiptera: Aphalaridae) in eucalyptus plantations. - Phytoparasitica 43: 151-158.

Flechtmann C., Ottati A. \& Berisford C. 2001: Ambrosia and bark beetles (Scolytidae: Coleoptera) in pine and eucalypt stands in southern Brazil. — For. Ecol. Manag. 142: 183-191.

Franco J., Garcia A. \& Branco M. 2016: First report of Epichrysocharis burwelli in Europe, a new invasive gall wasp attacking eucalypts. - Phytoparasitica 44: 443-446.

Friedman A., RitTNer O. \& ChiKatunov V. 2008: Five new invasive species of longhorn beetles (Coleoptera: Cerambycidae) in Israel. - Phytoparasitica 36: 242-246.

Gebeyehu S., Hurley B. \& Wingfield M. 2005: A new lepidopteran insect pest discovered on commercially grown Eucalyptus nitens in South Africa. - Sth. Afr. J. Sci. 101: 26-28.

Golan O. 2011: Abundance and Seasonal Activity of Eucalyptus Longed-horn Borers Phoracantha spp. Following the Invasion of P. recurva and Their Egg Parasitoid Avetianella longoi in Israel. MSc. Thesis, University of Jerusalem, 231 pp. [in Hebrew].

Gonçalves C., Vilas-Boas L., Branco M., Rezende G. \& VaLENTE C. 2019: Host susceptibility to Gonipterus platensis (Coleoptera: Curculionidae) of Eucalyptus species. - Ann. For. Sci. 76: 17-23.

Guershon M. \& Seplyarsky V. 2011: The Aleyrodidae of Israel. Biology, Distribution and Host Plant Associations. Plant Protection and Inspection Servives, Ministry of Agriculture and Rural Development, Bet Dagan, 20 pp. [in Hebrew].

HalPerin J. 1961a: Injury to eucalypts caused by Achradidius creticus Kies. and Opatroides punctulatus Bruelle. In: Contribution on Eucalypts in Israel. National \& University Institute of Agriculture, Ilanot, pp. 43-47.

HalPerin J. 1961b: Pests and diseases of eucalypts in Israel. In: Contribution on Eucalypts in Israel. National \& University Institute of Agriculture, Ilanot, pp. 19-22.

HaLPERIN J. 1973: Termites in forest and ornamental trees in Israel. - HaYaaran 23: 21-34 [in Hebrew].
HALPERIN J. 1976: Braconidae (Hymenoptera) associated with forest and ornamental trees and shrubs in Israel. - Phytoparasitica 14: 119-135.

Halperin J. \& Argaman Q. 2000: Annotated list of Buprestidae (Coleoptera) and their host plants of Israel. - Zool. Middle East 20: 99-116.

Halperin J. \& Damoiseau R. 1980: The bostrychid beetles (Coleoptera) of Israel. — Isr. J. Entomol. 14: 47-53.

HalPERIN J. \& Geis K. 1999: Lyctidae (Coleoptera) of Israel, their damage and its prevention. - Phytoparasitica 27: 257-262.

Halperin J. \& Holzschun C. 1993: Host-plants of Israeli Cerambycidae (Coleoptera), with new records. - Phytoparasitica 21: 23-37.

Halperin J. \& Sauter W. 1991: An annotated list with new records of Lepidoptera associated with forest and ornamental trees and shrubs in Israel. - Isr. J. Entomol. 25-26: 105-147.

Halperin J. \& StRassen R. 1981: Thysanoptera of forest and ornamental woody plants in Israel with a list of the species recorded from Israel. - Isr. J. Entomol. 15: 21-33.

Halperin J., Brosh S. \& Eshed N. 1989: Annotated List of Noxious Organisms in Ornamental Plants in Israel. Ministry of Agriculture, Extention Service, Tel Aviv, 92 pp.

Hanks L., Paine T. \& Millar J. 1993: Host species preference and larval performance in the wood-boring beetle Phoracantha semipunctata F. - Oecologia 95: 22-29.

Hanks L., Paine T., Millar J. \& Home J. 1995: Variation among Eucalyptus species in resistance to eucalyptus longhorned borer in Southern California. - Entomol. Exp. Appl. 74: 185-194.

Heller A., Rubin L., Galon I., Kagan S., Chercasky P., Fragman-Sapir O., Hadar-Gabay R., Kaslassi D., Drory I. \& ZIFFER-BERger J. 2017: List of the Ornamental Plants in Israel. Ministry of Agriculture and Rural Development, Bet Dagan, $220 \mathrm{pp}$.

Hodkinson I. 1999: Biocontrol of Eucalyptus psyllid Ctenarytaina eucalypti by the Australian parasitoid Psyllaephagus pilosus: a review of current programmes and their success. Biocontr. News Inf. 20: 129-130.

Jeddi K., Cortina J. \& Chaieb M. 2009: Acacia salicina, Pinus halepensis and Eucalyptus occidentalis improve soil surface conditions in arid southern Tunisia. - J. Arid. Environ. 73: 1005-1013.

Johnson L. \& Briggs B. 1981: Three old southern families Myrtaceae, Proteaceae and Restionaceae. In Keast A. (ed.): Ecological Biogeography of Australia. Springer, Hague, Utrecht, pp. 427-464.

KaRSCHON R. 1963: The introduction of eucalypts into Palestine. LaYaaran 13: 3-5 [in Hebrew].

Kenis M. \& Branco M. 2010: Impact of alien terrestrial arthropods in Europe. - BioRisk 4: 51-71.

Kozlowski T., Kramer P. \& Pallardy S. 1991: The Physiological Ecology of Woody Plants. Academic Press, San Diego, CA, $657 \mathrm{pp}$.

Lanfranco D. \& Dungey H. 2001: Insect damage in Eucalyptus: A review of plantations in Chile. - Aust. Ecol. 26: 477-481.

Laudonia S. \& Garonna A. 2010: The red gum lerp psyllid, Glycaspis brimblecombei, a new exotic pest of Eucalyptus camaldulensis in Italy. - Bull. Insectol. 63: 233-236.

Liphschitz N. \& Biger G. 2000: Green Dress for a Country, Afforestation in Eretz-Israel, the first Hundred Years 1850-1950. Ariel Publishing House, Jerusalem, 265 pp.

Lombardero M.J. \& Fernández De Ana Magán F.J. 1997: Nuevos insectos perforadores asociados al eucalipto en Galicia (Coleoptera: Scolytidae y Platypodidae). - Bol. San. Veg. Plagas 23: 177-188. 
Longo S., Palmeri V. \& Sommariva D. 1993: Sull attivita di Avetianella longoi ooparassitoide di Phoracantha semipunctata nell Italia meridionale. - Redia 76: 223-239.

Luhring K., Millar J., Paine T., Reed D. \& Christiansen H. 2004: Ovipositional preferences and progeny development of the egg parasitoid Avetianella longoi: factors mediating replacement of one species by a congener in a shared habitat. - Biol. Contr. 30: $382-39$.

Luiz-Queiroz D., Burckhardt D. \& Majer J. 2012: Integrated pest management of eucalypt psyllids (Insecta, Hemiptera, Psylloidea). In Marcelo L. \& Soloneski S. (eds): Integrated Pest Management and Pest Control - Current and Future Tactics. InTech Janeza Trdine, Rijeka, pp. 386-412.

MaAtouf N. \& Lumaret J. 2012: Eco-éthologie des nouveaux ravageurs invasifs des eucalyptus du Maroc. - Ann. Soc. Entomol. Fr. 48: 289-297.

MANSField S. 2016: New communities on eucalypts grown outside Australia. - Front. Plant Sci. 7: 1812, 9 pp.

Mapondera T., Burgess T., Matsuki M. \& Oberprieler R. 2012: Identification and molecular phylogenetics of the cryptic species of the Gonipterus scutellatus complex (Coleoptera: Curculionidae: Gonipterini). - Aust. J. Entomol. 51: 175-188.

Margiotta M., Bella S., Buffa F., Caleca V., Floris I., Giorno V., Verde G., Rapisarda C., Sasso R., Suma P., Tortorici F. \& LAUdonia S. 2017: Modeling environmental influences in the Psyllaephagus bliteus (Hymenoptera: Encyrtidae) - Glycaspis brimblecombei (Hemiptera: Aphalaridae) parasitoid-host system. - J. Econ. Entomol. 110: 591-501.

Matsuki M., Kay M., Serin J., Floyd R. \& Scott J. 2001: Potential risk of accidental introduction of Asian gypsy moth (Lymantria dispar) to Australasia: effects of climatic conditions and suitability of native plants. - Agric. For. Entomol. 3: $305-320$

Mazza G., Inghilesi A., Tricarico E., Montagna M., Longo S. \& Roversi P. 2015: First report of Gonipterus scutellatus complex (Coleoptera; Curculionidae) in Sicily (Italy). — Redia 98: $149-150$.

Mendel Z. 1987: Major pests of man-made forests in Israel: Origin, biology, damage and control. - Phytoparasitica 15: 131-137.

Mendel Z., Golan Y. \& Madar Z. 1984a: Natural control of the eucalyptus borer Phoracantha semipunctata (F.) (Coleoptera: Cerambycidae) by the Syrian woodpecker. - Bull. Entomol. Res. 74: 121-127.

Mendel Z. \& Protasov A. 2016: Invasive insect pest species of ornamentals in Israel. - Gan ve Nof 11-12: 24-30 [in Hebrew].

Mendel Z., Golan Y. \& Madar Z. 1984b: Studies on the phenology and mortality factors of the Eucalyptus borer (Phoracantha semipunctata) in Israel. - La-Yaaran 34: 30-44 [in Hebrew].

Mendel Z., Protasov A., Fisher N. \& La Salle J. 2004: Taxonomy and biology of Leptocybe invasa gen. \& sp. n. (Hymenoptera: Eulophidae), an invasive gall inducer on Eucalyptus. - Aust. J. Entomol. 43: 101-113.

Mendel Z., Protasov A., La Salle J., Blumberg D., Brand D. \& BRANCO M. 2017: Classical biological control of two Eucalyptus gall wasps; main outcome and conclusions. - Biol. Contr. 105: $66-78$

Mound L. \& Masumoto M. 2005: The genus Thrips (Thysanoptera: Thripidae) in Australia, New Caledonia and New Zealand. - Zootaxa 1020: 1-64.

Nazarian I. 2016: A Survey of Street Trees Held by the Tel AvivJaffa Municipality, the City Beautification Division. Tel Aviv, Jaffa, 13 pp. [in Hebrew].
NeUMARK S. 1953: The possibility of the control of agents attacking felled Eucalyptus camaldulensis by the application of a modified Boucherie process. In: Proc. XI Congr. IUFRO. Rome, pp. 685-694.

Novoselsky T. \& Freidberg A. 2016: First record of Thaumastocoris peregrinus (Hemiptera: Thaumastocoridae) in the Middle East, with biological notes on its relations with eucalyptus trees. - Isr. J. Entomol. 46: 43-55.

Paine T., Millar J. \& DaAne K. 2010: Accumulation of pest insects on eucalyptus in California: random process or smoking gun. - J. Econ. Entomol. 103: 1943-1949.

Paine T., Steinbauer M. \& Lawson S. 2011: Native and exotic pests of Eucalyptus: a worldwide perspective. - Annu. Rev. Entomol. 56: 181-201.

Peretz I. \& Cohen M. 1961: Apate monachus in Israel. - Pl. Prot. Bull. F.A.O. 9: 76-79.

Perez A., Otero R., Borrajo P., Mansilla J. \& Ruiz F. 2011: Primera cita en España de Psyllaephagus bliteus Riek (Hymenoptera: Encyrtidae), parasitoide de Glycaspis brimblecombei Moore (Hemiptera: Psyllidae). — Bol. San. Veg. Plagas 37: $37-44$.

Protasov A., Blumberg D., Brand D., La Salle J. \& Mendel Z. 2007a: Biological control of the eucalyptus gall wasp Ophelimus maskelli (Ashmead): taxonomy and biology of the parasitoid Closterocerus chamaeleon (Girault), with information on its establishment in Israel. — Biol. Contr. 42: 196-206.

Protasov A., La Salle J., Blumberg D., Brand D., Saphir N., Assael F., Fisher N. \& Mendel Z. 2007b: Biology, revised taxonomy and impact on host plants of Ophelimus maskelli, an invasive gall inducer on Eucalyptus spp. in the Mediterranean Area. - Phytoparasitica 35: 50-76.

Protasov A., Doganlar M., La Salle J. \& Mendel Z. 2008: Occurrence of two local Megastigmus species parasitic on the Eucalyptus gall wasp Leptocybe invasa in Israel and Turkey. - Phytoparasitica 36: 449-459.

Queiroz D., Keti M., Edilson B., Anjos N. \& Majer J. 2010: Feeding and oviposition preferences of Ctenarytaina spatulata Taylor (Hemiptera: Psyllidae) for Eucalyptus spp. and other Myrtaceae in Brazil. - Rev. Bras. Entomol. 54: 149-153.

Rassati D., Lieutier F. \& FAccoli M. 2016: Alien wood-boring beetles in Mediterranean regions. In Paine T. \& Lieutier F. (eds): Insects and Diseases of Mediterranean Forest Systems. Springer, Berlin, Heidelberg, pp. 293-327.

Rosen B. 1991: The introduction of the eucalyptus to Eretz Israel. - Cathedra 59: 195-102.

Roversi P.F. 1995: Studi su fecondità e fattori di mortalità in ovature di Lymantria dispar (L.) (Lepidoptera Lymantridae) deposte su Eucalyptus camaldulensis Dehn. — Redia 78: 283292.

Sama G., Buse J., Orbach E., Friedman L., Rittner O. \& ChikaTuNOV V. 2010: A new catalogue of the Cerambycidae (Coleoptera) of Israel with notes on their distribution and host plants. - Munis Entomol. Zool. 5: 1-51.

Spodek M., Burckhardt D., Protasov A. \& Mendel Z. 2015: First record of two invasive eucalypt psyllids (Hemiptera: Psylloidea) in Israel. - Phytoparasitica 43: 401-406.

StRASSEN R. \& KUSLITZKY W. 2012: An annotated checklist of the thrips of Israel (Thysanoptera). - Isr. J. Entomol. 41-42 [2011-2012]: 53-66.

Suma P., Nucifora S., Caleca V., Lo Verde G., Tortorici F., Rapisarda C. \& Bella S. 2018: A review on introduced alien insect pests and their associated parasitoids on Eucalyptus trees in Sicily. - Redia 101: 81-88.

Swirski E. \& Amitai S. 1999: Annotated list of aphids (Aphidoidea) in Israel. - Isr. J. Entomol. 33: 1-120. 
TEKeTAY D. 2000: Facts and experience on eucalypts in Ethiopia and elsewhere: ground for making wise and informed decision. - Walia 21: 25-46.

Thornhill A., Ho S., Kulheim C. \& CRISP M. 2015: Interpreting the modern distribution of Myrtaceae using a dated molecular phylogeny. - Mol. Phylogenet. Evol. 93: 29-43.

Valente C., Manta A. \& Vaz A. 2004: First record of the Australian psyllid Ctenarytaina spatulata Taylor (Homoptera: Psyllidae) in Europe. - J. Appl. Entomol. 128: 369-370.

Valente C., Gonçalves C., Monteiro F., Gaspar J., Silva M. Sottomayor M., Paiva M. \& Branco M. 2018: Economic outcome of classical biological control: a case study on the Eucalyptus snout beetle, Gonipterus platensis, and the parasitoid Anaphes nitens. - Ecol. Econ. 149: 40-47.
Waisel Y., NOAH I. \& FAHN A. 1966: Cambial activity in Eucalyptus camaldulensis Dehn. II. The production of phloem and xylem elements. - New Phytol. 65: 319-324.

Whitehead D. \& BeadLe C. 2004: Physiological regulation of productivity and water use in Eucalyptus: a review. - Ecol. Manag. 193: 113-140.

Wilcken E., Pereira J., Ribeiro Dias T., Zache B., Dal's M. \& Barbosa L. 2012: Biology of Thaumastocoris peregrinus in different Eucalyptus species and hybrids. - Phytoparasitica 40: 223-230.

YaKovlev R. 2011: Catalogue of the family Cossidae of the Old World. - Neue Entomol. Nachr. 66: 1-129.

Yakovlev R. \& Dubatolov V. 2013. Distribution of carpentermoths (Lepidoptera: Cossidae) in the Palaearctic deserts. Entomol. Rev. 93: 991-1004.

Received September 18, 2019; revised and accepted November 4, 2019 Published online November 28, 2019 